\title{
Editorial
}

\section{Sustainable Short Sea Shipping}

\author{
Anastasia Christodoulou *(1) and Johan Woxenius $(\mathbb{D}$ \\ Department of Business Administration, University of Gothenburg, SE-405 30 Gothenburg, Sweden; \\ johan.woxenius@gu.se \\ * Correspondence: anastasia.christodoulou@gu.se; Tel.: +46-31-786-6437
}

Received: 13 May 2019; Accepted: 16 May 2019; Published: 19 May 2019

\section{Background}

Sustainability in maritime transport has been an issue of major concern during the last decades. The significant growth of international trade and the consequent demand for maritime services, carrying more than $90 \%$ of global trade in volume, have led to the production of increased air emissions from shipping and their negative effects upon human health and climate change [1-3]. Over the years, various maritime stakeholders have taken initiatives for the abatement of maritime air emissions, with the most active being the International Maritime Organization (IMO)—responsible for the regulation of international shipping-and the European Union (EU) that has imposed a stricter regulatory framework within its territorial waters [4]. The IMO has proceeded in the development of Annex VI of its MARPOL Convention, where the technical and operational measures and policies for the abatement of shipping air emissions have been included.

An important initiative of the IMO for the reduction of shipping air emissions has been the designation of Sulphur Emission Control Areas (SECAs), governed by specific fuel oil sulphur limits for vessels as well as the decision to set a global sulphur limit from January 2020 onwards [5]. The imposition of these sulphur limits within SECAs has led shipping companies to undertake drastic measures to meet them. Recent literature has focused on the abatement costs and environmental benefits from the use of low sulphur fuel (marine gasoil (MGO), marine diesel oil (MDO), other fuels (e.g., liquified natural gas (LNG), methanol with fossil or renewable origin), or the installation of scrubbers at both individual firm and industry levels [6-8].

Besides the designation of SECAs, the IMO adopted two mandatory regulations targeting greenhouse gas (GHG) emissions from shipping that entered into force in January 2013: the Energy Efficiency Design Index (EEDI), a technical measure that aims to improve the energy efficiency level per capacity mile for vessels built after 2012 and the Ship Energy Efficiency Management Plan (SEEMP), an operational measure that pursues the operational energy efficiency improvement of a ship. The implementation of the SEEMP includes various operational measures-vessel speed reduction, just-in-time arrival of vessels at ports, better fleet planning - that are considered to have a great potential for GHG emission reductions [9-13].

Apart from the IMO regulations, the EU has adopted several EU directives targeting the abatement of shipping air emissions within its territorial waters. Under EU Directive 2012/33/EU, vessels operating within the exclusive economic zones of EU member countries which lie outside the European Emission Control Areas (ECAs) must use a maximum sulphur content fuel of $0.5 \%$ and a maximum sulphur content fuel of $0.1 \%$ while at berth in EU ports [14]. According to the most recent Directive 2014/94/EU, all Member States' maritime and inland waterway ports must build LNG refueling points and install onshore power supply (OPS) infrastructure for shore-side electricity by the end of 2025 [15]. The installation of OPS in ports enables vessels to turn off their auxiliary engines and use shore-side electricity for their activities while at berth and could result in significant emission reductions at ports $[16,17]$. 
Deep sea shipping is generally accepted as the most environmentally friendly and energy efficient mode of transport. It is also true for large segments of short sea shipping (SSS), here simply defined as maritime transport that does not cross oceans. The sustainability performance of the SSS signature market segment of Roll on-roll off (RoRo) and Roll on-Roll off Passenger (RoPax), however, has been strongly questioned due to the generally low load factor and high operational speeds $[18,19]$.

SSS is less researched than deep sea shipping and it deserves more scientific attention. This is particularly true for the market segment of RoRo and RoPax. However, SSS also includes dry and wet bulk, ferry services and, with the operational definition of this Special Issue, transport on inland waterways as well. This issue intends to enrich and expand the existing literature on sustainable maritime transport, taking into consideration the particular operational and organizational features of SSS. Under this consideration, six papers covering sustainability issues of SSS operations in three continents have contributed to this Special Issue.

\section{Contributions}

There are several operational measures suggested for the improvement of the operational energy efficiency of vessels. Among these measures, slow steaming is considered to have a great potential for GHG emission reductions with a parallel decrease in fuel consumption and related costs for the shipping companies. Raza, Woxenius, and Finnsgård (Contribution 1) examined the reaction of the RoRo and RoPax shipping firms operating in the North and Baltic Seas toward slow steaming as a mitigating factor for the increased costs required for the compliance with the stricter sulphur limits within SECAs. The authors further analyzed the impact of slow steaming on the competitiveness of short sea RoRo and RoPax with respect to service quality. One interesting result in this paper is that the SECAs' fuel sulphur limits have not led to slow steaming in the RoRo and RoPax segments to a large extent, with the increased fuel costs being partially transferred to the shippers via an increased bunker adjustment factor and partly borne by the shipping lines. Out of 11 case firms included in this study, only one RoRo and one RoPax firm have reduced vessel speeds as a result of the additional costs for the compliance with SECA regulations. Although the potential of slow steaming as a response to increased operational costs within SECAs has been investigated in previous research, the novelty of this paper is the use of qualitative methodology to address this issue. This paper contributes to highlighting the importance of meeting service quality requirements from a wide variety of shippers and travelers and the rigorous competition within the RoPax and RoRo segments that have significantly restricted the potential implementation of slow steaming.

Considering the stricter environmental regulations within SECAs, Stalmokaite and Yliskylä-Peuralahti (Contribution 2) explored the effect from the imposition of this regulatory framework on the decisions of SSS firms operating in the Baltic Sea for the adoption of environmental innovations and alternative vessel energy sources. By drawing on a multi-level perspective from the socio-technical transition literature, the authors provide empirical evidence on the individual shipping companies' motivation to invest in maritime niche technologies. They highlight the conditions under which policy interventions might stimulate or hamper sustainability transitions in the shipping sector. The authors point out that the environmental sulphur regulation was crucial for the motivation of shipping companies to adopt environmental innovations, but it was a combination of evolving pressures in their external landscape environment (economic fluctuations, increasing societal demands for cleaner transportation) and companies' task environments (market opportunities, customer demands, and the moves of competitors) that played an additional role for the investment in niche technologies. The need for a holistic approach in the design of command-and-control regulations in shipping is underlined in this paper, taking into consideration that the main challenges are linked to implementing these regulations in practice. Finally, the authors highlight the importance of market-based policy instruments for rewarding proactive shipping companies for going beyond compliance in order to stimulate sustainability transitions in shipping. 
The integration of SSS in European intermodal transport chains has been an issue of major concern during the last decades due to the environmental and social benefits that it offers compared to road transport and the fact that it can facilitate the connection of remote and peripheral regions without requiring high infrastructure investments [15]. Nevertheless, the level of integration of shipping in intermodal transport chains has been quite slow. In the existing literature, the topic of SSS and its integration into the intermodal transport chain has mostly been studied from the transport providers' perspective, while the role of a shipper has received little attention. Through an in-depth case study, Christodoulou, Raza, and Woxenius (Contribution 3) investigated the operation of RoRo shipping services in Northern Europe, focusing on the role that shippers can play for the integration of multiple traffic modes into a seamless intermodal transport chain and identifying the main barriers that prevent RoRo shipping from being a viable alternative to road transport for certain transport routes. According to their findings, cooperation and shared planning among transport chain agents and a different management approach are among the key drivers for SSS integration into intermodal transport chains, whereas high cargo-handling costs in ports represent one of the top barriers for the further employment of SSS services. Large shippers, having control of large cargo volumes, can play a vital role in the integration of multiple traffic modes as they can ensure high frequency of a transport service for smaller forwarders and shippers as well as increased capacity utilization of a traffic mode for transport providers. Furthermore, intermodal integration between different traffic modes or strategic collaboration between transport chain agents (cargo owners, ship operators, and forwarding agents) can lead to improved system efficiency and reduced lead times, emissions, and costs as well as additional revenues for all collaborating parties.

The crucial role of ports for the provision of reliable, quality, and safe SSS services was explored by Michaelides, Herodotou, Lind, and Watson (Contribution 4), who considered the effect of port-2-port (P2P) communication on the port efficiency of SSS hubs, focusing on Cyprus and the Eastern Mediterranean. The authors investigated the factors influencing the various waiting times at the Port of Limassol, from both a qualitative and a quantitative perspective. The qualitative research included the views of key stakeholders involved in the port call process, whereas the quantitative analysis was based on 8070 port calls to the Port of Limassol completed between 1 January 2017 and 13 December 2018. The exploration of three important factors that can influence port efficiency-the vessel type, the port of origin, and the role of the shipping agent in managing a vessel's schedule-was used for the calculation of three key performance indicators (KPIs) that included arrival punctuality, berth waiting, and berth utilization. A novel aspect of this analysis is the consideration of shipping agents as a determinant factor that affects port efficiency and the link of the shipping agent's performance to reduced waiting times at ports. The analysis clearly shows a considerable variation in shipping agent performance with regard to planning the arrival and berthing of a ship in Limassol, with poor performing agents reducing port efficiency and causing traffic disruptions and increased environmental impact due to vessels waiting out of the port. Based on the principles of Port Collaborative Decision Making (PortCDM), the authors suggest the inclusion of P2P communication, data sharing, and information transparency among all actors involved in a port call process for the enhancement of a shipping agent's performance and the consequent improvement of a port's efficiency.

The potential from the use of alternative fuels (such as LNG, liquefied biogas, methanol, and bio-methanol) for the improvement of the environmental impact from shipping has been underlined by recent literature. Nevertheless, in many cases the employment of different alternative fuels leads to the effective reduction of some air pollutants having, though, negative effects on other shipping emissions. By applying a total fuel cycle analysis (TFCA), Winebrake, Corbett, Umar, and Yuska (Contribution 5) made a life-cycle emissions analysis of methanol (MeOH), LNG, and low sulphur MDO and evaluated emissions along the fuel production and delivery pathway, including feedstock extraction, processing, distribution, and use in the United States. The authors explored the pollution tradeoffs of these fuels in relation to GHGs, particulate matter $\left(\mathrm{PM}_{2.5}\right)$, sulfur oxides (SOx), and nitrogen oxides (NOx), considering both near-term (20 years) and long-term (100 years) potential climate 
impacts. A novel aspect of this paper is the evaluation of the impacts of methane $\left(\mathrm{CH}_{4}\right)$ leakage within the natural gas recovery, processing, and distribution stages of its fuel cycle through an uncertainty analysis. The results show that $\mathrm{MeOH}$ and $\mathrm{LNG}$ perform better than MDO with respect to local air pollutants $\left(\mathrm{PM}_{2.5}, \mathrm{SOx}\right.$, and $\left.\mathrm{NOx}\right)$, although their environmental benefits in relation to GHG emissions depend on the source the natural gas is derived from. In particular, both the near-term and the long-term GHG footprint of $\mathrm{MeOH}$ derived from natural gas from conventional wells and shale formations is $\approx 20 \%$ and $\approx 10 \%$ higher than MDO, respectively. Nevertheless, when derived from renewable biomass, $\mathrm{MeOH}$ performs better than $\mathrm{MDO}$, exhibiting approximately 20-25\% reductions in GHGs. The results are demonstrated in absolute terms in an East Coast short sea shipping case study including a trip from Jacksonville, Florida to the Port of New York. The use of MeOH and LNG leads to emission reductions of up to $90 \%$ on local air pollutants (NOx, $\mathrm{PM}_{2.5}$, and SOx), although the performance of these fuels with regard to GHGs is worse than that of MDO. Their use results in $\approx 480$ metric tons of GHG emissions, whereas for the same trip about $20 \%$ less ( $\approx 400$ metric tons of GHG) are emitted using MDO. These results highlight the importance that renewable liquified gas can play in the shipping sector. Effective incentives for the promotion of natural gas-based fuel use must be developed by policy makers, including tighter regulation of the energy efficiency of vessel designs and emission control standards in natural gas production systems.

The potential of SSS in an African context was explored by Konstantinus, Zuidgeest, Christodoulou, Raza, and Woxenius (Contribution 6). Although there is extensive literature on SSS operations in Europe, America, and Asia, it is the first time that the development of SSS in Africa is considered. The authors identified the main barriers and enablers of SSS in the Southern African Development Community (SADC) region, an economic community of 16 countries in Southern Africa, and underlined policy initiatives that could enhance SSS development in the area. The development of an effective regional freight transport system plays a crucial role in achieving the strategic goals set forth by the SADC and related to development, peace, security, and economic growth. SSS in the SADC would offer three main transport services: unimodal freight transport between port cities, the main leg of an intermodal route, and feeder services to deep sea shipping in a hub-and-spoke system. The results indicate that the large geographic region, projected freight volumes, customs, and trade policies within the SADC region could enable the development of SSS in the area. Nevertheless, low port competitiveness, customs provisions, and policies for intra-regional trade represent issues that must be addressed.

\section{Conclusions}

Sustainability in maritime transport has been an issue of major concern during the last decades, with a growing number of scientific studies dealing with this topic. Nevertheless, the focus has almost exclusively been on deep sea shipping, not taking into consideration the particular operational and organizational features of SSS. At least in Europe, studies about SSS has rather been published as reports and presentations and often as deliverables from policy- and impact-driven EU-funded projects. As such, it is an example of the phenomenon of curiosity-driven and impact-driven research drifting apart, where the former publish and cite scientific journal articles and the latter is restricted to the grey literature [20].

This Special Issue intends to enrich and expand the existing scientific literature on sustainable maritime transport, focusing on the sustainability aspects of SSS. Given that SSS is considered as maritime transport that does not cross oceans, geographical variation is quite important. SSS operations in three different continents (Europe, America, and Africa) are included in this Special Issue. In Europe, three different seas, the Mediterranean, North Sea, and Baltic Sea, serve as empirical context.

The first three papers deal with the response of shipping companies to the stricter environmental regulatory framework related to maritime transport in Northern Europe. The potential of slow steaming for the mitigation of the increased operational costs from SECAs is explored in the first paper, while the second one investigates the role of regulatory regimes for the investment in maritime 
niche technologies. The role of shippers for the further use of RoRo shipping services and their integration into sustainable intermodal chains is examined in the third paper. The fourth paper highlights the crucial role of ports for the provision of reliable and quality SSS services and analyzes the role of port-2-port (P2P) communication for the enhanced port efficiency of SSS hubs in the Eastern Mediterranean. The potential of natural gas-based fuels for the abatement of maritime air emissions in the United States is explored in the fifth paper, while the sixth paper focuses on the enablers and barriers for the development of SSS services in Southern Africa.

Although the contributions in this Special Issue do not include all aspects of sustainable maritime transport, they cover topics related to the use of alternative fuels in shipping, slow steaming, investments in innovative technologies, and the role of ports for sustainable maritime operations. The need for the adoption of effective policies and the provision of economic incentives that would stimulate the investment in niche maritime technologies or the use of alternative fuels has been highlighted in this Special Issue, along with the importance of collaboration and shared planning among the maritime chain actors (including ports) for the achievement of sustainable maritime development.

\section{List of Contributions}

1. Raza, Z., Woxenius, J., and Finnsgård, C. Slow Steaming as Part of SECA Compliance Strategies among RoRo and RoPax Shipping Companies.

2. Stalmokaitè, I., and Yliskylä-Peuralahti, J. Sustainability Transitions in Baltic Sea Shipping: Exploring the Responses of Firms to Regulatory Changes.

3. Christodoulou, A., Raza, Z., and Woxenius, J. The Integration of RoRo Shipping in Sustainable Intermodal Transport Chains: The Case of a North European RoRo Service.

4. Michaelides, M.P., Herodotou, H., Lind, M., and Watson, R.T. Port-2-Port Communication Enhancing Short Sea Shipping Performance: The Case Study of Cyprus and the Eastern Mediterranean.

5. Winebrake, J.J., Corbett, J.J., Umar, F., and Yuska, D. Pollution Tradeoffs for Conventional and Natural Gas-Based Marine Fuels.

6. Konstantinus, A., Zuidgeest, M., Christodoulou, A., Raza, Z., and Woxenius, J. Barriers and Enablers for Short Sea Shipping in the Southern African Development Community.

Author Contributions: A.C. and J.W. shared the guest editorial work. A.C. drafted the manuscript and J.W. reviewed and revised the manuscript.

Funding: The research funding was channeled by the Maritime Competence Centre Lighthouse.

Conflicts of Interest: The authors declare no conflict of interest. The funders had no role in the design of the study; in the collection, analyses, or interpretation of data; in the writing of the manuscript; or in the decision to publish the results.

\section{References}

1. Smith, T.W.P.; Jalkanen, J.P.; Anderson, B.A.; Corbett, J.; Faber, J.; Hanayama, S.; O’Keeffe, E.; Parker, S.; Johansson, L.; Aldous, L. Third IMO GHG Study; International Maritime Organization (IMO): London, UK, 2014.

2. Cullinane, K.; Cullinane, S. Atmospheric emissions from shipping: The need for regulation and approaches to compliance. Transp. Rev. 2013, 33, 377-401. [CrossRef]

3. Corbett, J.J.; Winebrake, J.J.; Green, E.H.; Kasibhatla, P.; Eyring, V.; Lauer, A. Mortality from Ship Emissions: A Global Assessment. Environ. Sci. Technol. 2017, 41, 8512-8518. [CrossRef]

4. Christodoulou, A.; Gonzalez-Aregall, M.; Linde, T.; Vierth, I.; Cullinane, K. Targeting the reduction of shipping emissions to air: A global review and taxonomy of policies, incentives and measures. Marit. Bus. Rev. 2019, 4, 16-30. [CrossRef] 
5. IMO. Amendments to the Annex of the Protocol of 1997 to amend the International Convention for the Prevention of Pollution from Ships, 1973, as modified by the Protocol of 1978 relating thereto. Rev. MARPOL Annex VI 2008, 56, 176.

6. Rennings, K.; Rammer, C. The Impact of Regulation-driven Environmental Innovation on Innovation Success and Firm Performance. Ind. Innov. 2011, 18, 255-283. [CrossRef]

7. Cainelli, G.; Mazzanti, M. Environmental innovations in services: Manufacturing-services integration and policy transmissions. Res. Policy 2013, 42, 1595-1604. [CrossRef]

8. Cullinane, K.; Bergqvist, R. Emission control areas and their impact on maritime transport. Transp. Res. Part. D Trans. Environ. 2014, 28, 1-5. [CrossRef]

9. Winnes, H.; Styhre, L.; Fridell, E. Reducing GHG emissions from ships in port areas. Res. Transp. Bus. Manag. 2015, 17, 73-82. [CrossRef]

10. Bouman, E.A.; Lindstad, E.; Rialland, A.I.; Strømman, A.H. State-of-the-art technologies, measures, and potential for reducing GHG emissions from shipping-A review. Transp. Res. Part. D Transp. Environ. 2014, 52, 408-421. [CrossRef]

11. Miola, A.; Marra, M.; Ciuffo, B. Designing a climate change policy for the international maritime transport sector: Market-based measures and technological options for global and regional policy actions. Energy Policy 2011, 39, 5490-5498. [CrossRef]

12. Johnson, H.; Johansson, M.; Andersson, K.; Södahl, B. Will the ship energy efficiency management plan reduce CO2 emissions? A comparison with ISO 50001 and the ISM code. Maritime Policy Manag. 2013, 40, 177-190. [CrossRef]

13. Goulielmos, A.; Giziakis, C.; Christodoulou, A. A future regulatory framework for $\mathrm{CO} 2$ emissions of shipping in the Mediterranean Area. Int. J. Euro-Mediterr. Stud. 2011, 4, 39-60.

14. European Union. Directive 2012/33/EU of the European Parliament and of the Council of 21 November 2012 Amending Council Directive 1999/32/EC as Regards the Sulphur Content of Marine Fuels. Available online: http://data.europa.eu/eli/dir/2012/33/oj (accessed on 28 April 2019).

15. European Union. Directive 2014/94/EU of the European Parliament and of the Council of 22 October 2014 on the Deployment of Alternative Fuels Infrastructure. 2014. Available online: http://data.europa.eu/eli/dir/ 2014/94/oj (accessed on 28 April 2019).

16. Acciaro, M.; Ghiara, H.; Cusano, M.I. Energy management in seaports: A new role for port authorities. Energy Policy 2014, 71, 4-12. [CrossRef]

17. Ballini, F.; Bozzo, R. Air pollution from ships in ports: The socio-economic benefit of cold-ironing technology. Res. Transp. Bus. Manag. 2015, 17, 92-98. [CrossRef]

18. Hjelle, H.M. Short Sea Shipping's Green Label at Risk. Trans. Rev. 2010, 30, 617-640. [CrossRef]

19. López-Navarro, M.Á. Environmental Factors and Intermodal Freight Transportation: Analysis of the Decision Bases in the Case of Spanish Motorways of the Sea. Sustainability 2014, 6, 15-44. [CrossRef]

20. Woxenius, J. The consequences of the extended gap between curiosity-driven and impact-driven research. Transp. Rev. 2015, 35, 401-403. [CrossRef]

(C) 2019 by the authors. Licensee MDPI, Basel, Switzerland. This article is an open access article distributed under the terms and conditions of the Creative Commons Attribution (CC BY) license (http://creativecommons.org/licenses/by/4.0/). 